\title{
The Effectiveness of the Vocational High School
}

\author{
Heni Mulyani \\ Faculty of Economic and Business Education \\ Universitas Pendidikan Indonesia \\ henimulyani@upi.edu
}

\begin{abstract}
The research problem is related to the structure of the relationship variables that affect the effectiveness of the Vocational High School of Business and Management Expertise in West Java directly or indirectly, which consists of school leadership, school climate, community participation, and the teachers' teaching performance. The research method used Explanatory Survey Method. Data collection technique was using questionnaires. The research samples were 210 vocational schools in West Java. Data processing technique was using Structure Equation Models. The results of this study indicate that all models of the structure of the exogenous variables consisting of school leadership, school climate, community participation, and the performance of the teachers have significant influence on the effectiveness of Vocational High School, as an endogenous variable.
\end{abstract}

Keywords: School Effectiveness, School Leadership, School Climate, Community Participation, Teachers' Performance

\section{INTRODUCTION}

The expectations of the government towards Vocational High School in order to combat unemployment and improve social welfare are inevitable. But on the other hand the performance Vocational High School is still not optimal. This is marked by the achievement of success indicators in vocational education are not yet optimal [1]. One of the indicators related to the absorption of Vocational High School graduates by the business and industry, nationally in 2008 Vocational High School graduates who can immediately enter the workforce approximately $80-85$ percent, while all this is absorbed 61 percent [2]. These data indicate the effectiveness of the Vocational High School is not yet optimal.

The urgency of increasing the school effectiveness based on the argument that the effectiveness of the school contains an indicator of expectations of achievement of the objectives of education systemically. Effectiveness indicators can be derived for each phase of the open-system cycle-inputs (human and financial resources), transformations (internal process and structures) and outputs (performance outcomes). At one time or another, virtually every input, transformation or outcome variable has been used as an indicator of organizational effectiveness [3].
School effectiveness shows the school's ability to perform its functions optimally to achieve the goals that have been set; so as to improve the quality of education is necessary to the effectiveness of the school as an institution of education providers. One of a measure that indicates quality of education in schools is the school's accreditation. Accreditation indicates that the school can meet the standards of education in schools. Thus we can say that a school that has achieved "A" accreditation is a school that has achieved the effectiveness, because it is able to optimize the capacity and perform its functions in order to achieve the goals set. Most of the Vocational High School in West Java has not achieved "A" accreditation. From 779 schools, 262 schools have been accredited as "A" (approximately 33.63\%), while the remaining $66.37 \%$ is not accredited as " $\mathrm{A}$ ". This indicates that there are still many schools that have not been able to meet the standards of the organization that has been set. So there is still need for improvement of the indicators of quality of education to achieve the expected standards.

\section{LITERATURE REVIEW}

Organizational effectiveness is the extent to which an organization has met its stated goals and objectives and how well it performed in the process [4]. Based on the theory of organizational effectiveness, the effectiveness of which has not been optimal in the educational unit is predicted as a result of non-optimal implementation and optimization of fulfillment of the indicators which is a prerequisite and determine the effectiveness of school organization, including: a) the principal's leadership; b) The school climate; c) the teachers' teaching performance; and d) the lack of community participation in the school's progress in the form of physical, material, financial, and contribute ideas [5].

Measuring the school effectiveness based on the achievement of objectives can be described as the classic approach, however, remains a functional way, effective, efficient and easy. Only the use of this approach should be accompanied by a few notes: (1) the purpose of the school is not solely measured by student achievement not to say merely achievement; (2) the school as an organization also has the size of the effectiveness of such satisfaction and job performance of teachers, participation and parental 
satisfaction as a customer, leadership effectiveness, the continuation of schools and other organizations.

Furthermore, the school's success in realizing the effectiveness can be measured by using measurements based on five dimensions: quantity and quality of products, efficiency, adaptability, and flexibility [6].

\section{RESEARCH METHODOLOGY}

The method used was Explanatory Survey Method. This study consisted of a variable dependent is the effectiveness of the school (Y), and the factors that influence the effectiveness of the school consisting of four variables, namely school leadership (X1), school climate (X2), community participation (X3) and the teachers' teaching performance (X4). Principal leadership is translated into three sub-variables: direction setting, directing people, and redesigning the organization. School Climate consists of sub-variable: collegial leadership, professional teacher behavior, achievement press, and the institutional vulnerability. Community Participation consists of planning, implementation, and evaluation. Teachers' teaching performance consists of focus on students and learning, content / learning materials, and learning practice. School effectiveness consists of five sub-variables: the forms of service, quality of service, efficiency, adaptability, and flexibility.

The units of analyses were the Vocational High Schools of Business and Management Expertise in West Java, so that the population in this study was 466 Vocational High Schools comprising of 44 public and 422 private Vocational High Schools. To determine the number of sample (210 schools) used in this study proportionated stratified random sampling technique to distinguish between Public Vocational High School and Private Vocational High School, and to distinguish between accredited school A, B, and C. Data analysis techniques used in this research was Structural Equation Models. The reason using this technique is to explain thoroughly the relationship between the variables that exist in the research.

\section{RESUlt AND Discussion}

Overall, Structural Equation Modeling the influence of variables Principal Leadership (X1), School Climate (X2), Community Participation (X3), and Teachers' Teaching Performance (X4) to School Effectiveness (Y) can be described as follows: 


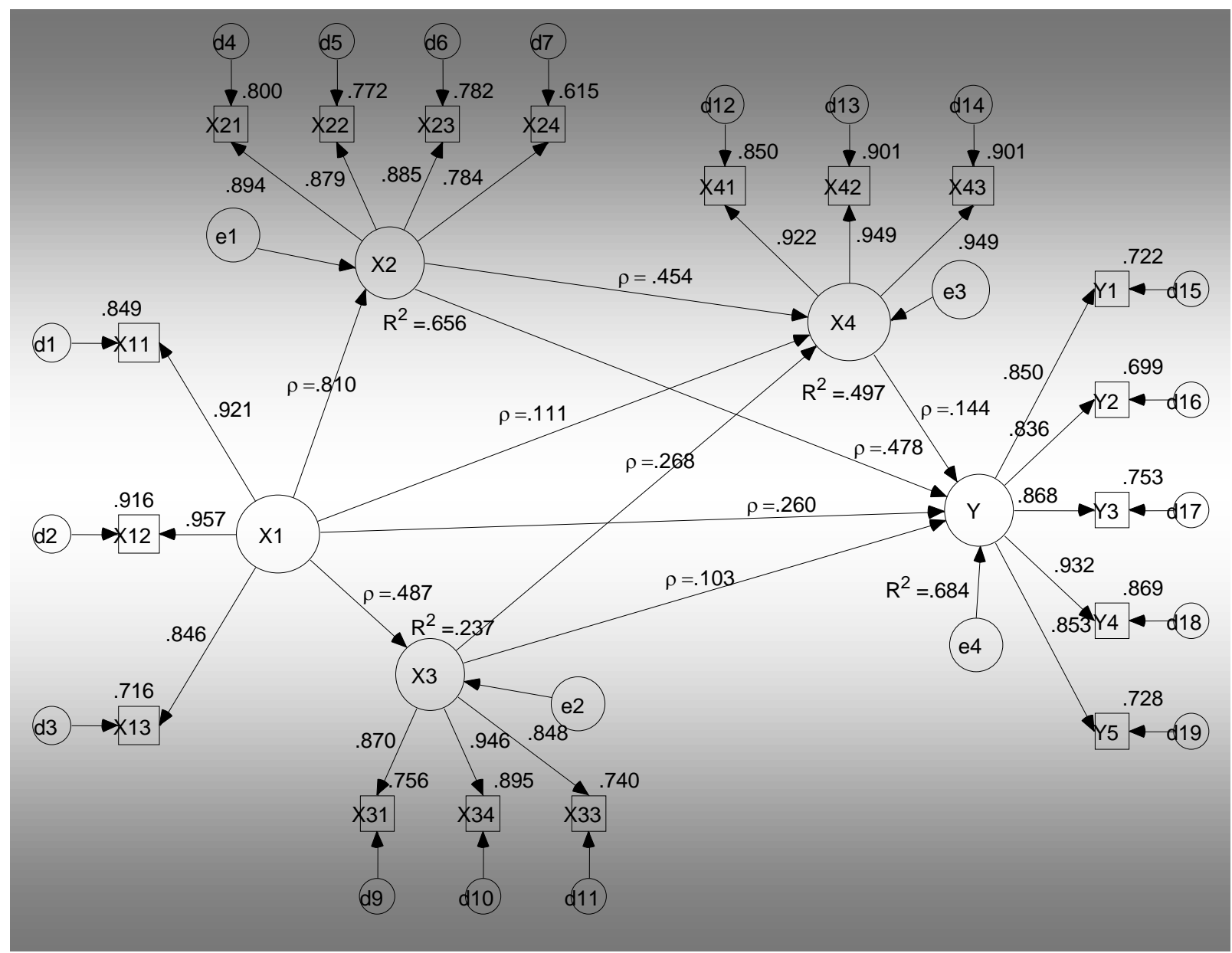

Figure 1

Overall Structural Equation Modeling the influence of variables X1, X2, X3, and X4 to Y

The total effect of the Principal Leadership clearly has great potential to influence school climate and the Community Participation, so its influence on the Performance of Teachers and School Effectiveness can be even greater, as showed in the table below:

Table 1. Total Effect of X1, X2, X3 on X4 and Y

\begin{tabular}{|r|rrrrr|}
\hline $\begin{array}{r}\text { Total } \\
\text { Effect }\end{array}$ & $\mathrm{X} 3$ & $\mathrm{X} 2$ & $\mathrm{X} 1$ & $\mathrm{X} 4$ & $\mathrm{Y}$ \\
\hline $\mathrm{X} 4$ & 0,268 & 0,454 & 0,610 & & \\
$\mathrm{Y}$ & 0,103 & 0,545 & 0,753 & 0,148 & \\
\hline
\end{tabular}

Source: Data Processing (2015)

Empirically, the principal leadership as driver variable is proven can trigger variables process consisting of school climate, community participation, and teachers' teaching performance so as to improve the effectiveness of the school.
Hypothesis testing results indicate that the influence of the Principal Leadership on the school climate is statistically significant, with figures path coefficient of 0.810 and $\mathrm{t}$ calculated at 31.316. These test results indicate that school leadership is an essential component in the school to support a favorable school climate. From findings of this study proved that the principal should have the ability to direct the environment, directing people, and the redesign of the organization, so as to create a school climate that is conducive to the creation of a conducive environment can trigger teacher performance is increased and better. This means that principal leadership determine school climate. In confirms that an effective school leadership has an influence on the creation of school climate [7]. This is in line with the proposed by Stupak that leader function is to create the atmosphere and the climate where members of the organization can develop [8].

Hypothesis testing results indicate that the influence of the Principal Leadership on Community participation is 
statistically significant, with figures path coefficient of 0.487 and $\mathrm{t}$-calculated at 15.823 . These results indicate that school leadership can improve community participation in the vocational high school of business and management expertise in West Java in achieving its objectives. The quality of school partnerships with business and industry co-determined by the leadership of the principal, which consists of directing the environment, directing people, and the redesign of the organization. Based on empirical findings, in developing school goals, head of the vocational skills of business and management in West Java include the participation of teachers and the community.

Directly, the influence of the Principal Leadership on the teachers' teaching performance is also statistically significant, with figures path coefficient of 0.111 and t-stat of 2.322 . While the influence of the total (direct and indirect through the school climate and community participation) on leadership principal on the teachers' teaching performance is equal to 0.610 . The result of this calculation indicates that the teachers teaching performance in vocational school of business and management expertise in West Java is directly influenced by the school leadership. In addition, the calculation results indicate that the school leadership through school climate and community participation can affect the performance of teachers to teach. This means that community participation is supported by the school leadership and its interaction with the climate of the school is an important component in improving the teachers' teaching performance of vocational school. This indicates that a school requires community participation in its efforts to improve the performance of teachers to teach. Therefore, the relationship between the school and the community should be established in harmony, that the relationship between school and society essentially a tool that can play a role in fostering and developing the personal growth of students in school [9].

The school leadership, directly and indirectly, has an influence on the effectiveness of the school. Empirically, the direct effect of principal leadership on School Effectiveness is statistically significant, with figures path coefficient of 0.260 and $\mathrm{t}$-stat equal to 6.421. In this case, the effect of the total (direct and indirect through school climate, community participation, and teachers' teaching performance) of the principal leadership on school effectiveness is approximately 0.753. Directly, the influence of the school climate on school effectiveness is also statistically significant, with figures path coefficient of 0.478 and t-stat at 11.135. While the influence of the total (direct and indirect through teachers' teaching performance) on school climate on school effectiveness is equal to 0.545 .The influence of community participation, directly and indirectly, on school effectiveness. Direct influence of community participation on school effectiveness is also meaningful or statistically significant, with figures path coefficient of 0.103 and $\mathrm{t}$-stat of 3.315 (more than 1.96). In this case, the total effect (direct and indirect through teachers' teaching performance) on community participation on school effectiveness is equal to 0.172 . The direct effect of the teacher's performance on school effectiveness is statistically significant, with path coefficient of 0.148 and t-stat 5.052.

The research finding is in line with the results of the study suggest that a model of the relationship of leadership, the quality of teacher performance and student learning in improving school effectiveness. In this case, the school environment can mediate leadership with the quality of teacher performance and student learning. In classes, the principal may moderate the influence of the quality of teacher performance in student learning. Overall this model confirms leadership contribution to the improvement of the effectiveness of teacher performance and increases the consistency of effective schools [10]. Likewise, the result of research, which states that one of the factors that affects the performance of teachers, is the community participation. Community participation is to increase the motivation of teachers in performing their duties so as to display the performance of learning progressively increasing [11].

\section{CONCLUSION AND SUGGESTION}

In general, the result shows the structure of the variables relationship that affect directly or indirectly on the Effectiveness of Vocational High School in West Java province, consisting of school leadership, school climate, community participation, and teaching performance of teachers, supported by empirical facts. That is based on the structural model test of the hypothesis, all paths of exogenous variables consisting of school leadership, school climate, community participation, and teachers' teaching performance to the effectiveness of vocational schools, as endogenous variables is significant.

In general, refers to the factors that influence the effectiveness of the school, the factor that has contributed to the lowest is community participation in the form of a partnership between the school and the business and industry. Based on these results suggested recommendation the school to further encourage and increase the participation of the business and industry by identifying the needs of business and industry to schools and identify what can be done by schools to meet these needs, giving rise to the satisfaction of the business and the industry. With the existence of such satisfaction, the school can meet their need for participation of the business and industrial to school. In addition, school partnerships with business and industry can be improved through optimization of the role of the school committee, the juridical basis of formal clear and decisive organize school partnerships with business and industry, and is based on a memorandum of understanding (MoU) between the school and the business and industry in establishing partnerships. 
And most important of it all is the creation of a school environment through the leadership of the principal, so as to increase community participation; teachers' teaching performance and will ultimately increases the effectiveness of the school.

The results of this study have implications for increasing the effectiveness of vocational schools should be done through a program that is planned well for increasing the effectiveness of schools planned to programs that are less integrated and less intact as a policy will have implications for the achievement of process quality and output quality of education in Vocational high School. Need to plan an integrated program, mature, definitely, and comprehensive so that the purpose, direction, goals and desired outcomes are measurable, clear and accountable indicators, there should be a shared perception of school administrators about school effectiveness, it is also about the rule or policy which becomes foothold program to improve school effectiveness and the basic guidelines, general guidelines and specific guidelines for implementation.

\section{REFERENCE}

[1] Suyanto. Perumusan Manajemen Berbasis Sekolah, 2007.

[2] Samsudi. Daya Serap Lulusan SMK Masih Rendah, 2008.

[3] Hoy, W.K and Miskel, C.G.. Educational Administration: Theory, Research and Practice. New York: McGraw Hill, 2008.

[4] Yankey, J. A., \& McClellan, A. (2003). The nonprofit board's role in planning and evaluation. Book Seven of the BoardSource Governance Series. Quoted in "Nonprofit Organizational Effectiveness". International Journal of Business and Behavioral Sciences.

[5] Steers, R. (1985). Organizational Effectiveness. New York: McGraw Hill.

[6] Hoy, W.K., Smith, P.A. and Sweetland, S.R. (2002). The Development of The Organizational Climate Index for High Schools : Its Measure and Relationship to Faculty Trust. The High School Journal, 86 (2).

[7] Kelley, R.C., Thornton, B., Daugherty, R.. Relationship Between Measures of Leadership and School Climate. Journal of Educational Management, 2005.

[8] Stupak, R. (2008). Symposium on Organizational Culture: Theory, Practice, and Cases. Public Administration and Management: An Interactive Journal, http://www.pmaji.com/-doc3.html.

[9] Mulyasa, E. Menjadi Kepala Sekolah Profesional. Bandung: Rosdakarya Remaja, 2006.

[10] Heck, R. and Hallinger, P. Modelling the Longitudinal Effects of School Leadership on Teaching and Learning. Journal of Educational Administration, 2014, 52(5), 653-681.

[11] Nadeem, M. Teacher's Competencies and Factors Affecting the Performance of Female Teachers In Bahawalpur (Southern Punjab) Pakistan. International Journal of Business and Social Science , 2011, Vol. 2, No. 19, 217-222. 